\title{
PENGARUH PARAMETER PENGELASAN RESISTANCE SPOT WELDING TERHADAP SIFAT FISIK DAN MEKANIK MULTI-LAYER IOGAM TAK SEJENIS BERBEDA KETEBALAN
}

\author{
Haikal $^{1}$, Moch.Chamim ${ }^{1}$, Edy Suryono ${ }^{1}$, Fatimah Nur Hidayah ${ }^{1}$, Triyono ${ }^{2}$ \\ ${ }^{1}$ Program Studi Teknik Mesin, Sekolah Tinggi Teknologi Warga Surakarta \\ ${ }^{2}$ Program Studi Teknik Mesin, Universitas Sebelas Maret \\ E-mail: haikal@sttw.ac.id
}

\begin{abstract}
Abstrak
Penggunaan resistance spot welding untuk menggabungkan logam tiga lapis merupakan pengembangan baru dalam perakitan automotif. Pengaruh parameter pengelasan seperti tegangan listrik dan waktu pengelasan terhadap sifat fisik dan mekanik sambungan las logam tak sejenis antara 316L, SS 400, dan J1 telah diteliti. Gaya penekanan elektroda dalam penelitian ini dibuat seragam. Parameter pengelasan yang digunakan yaitu tegangan 2,$02 ; 2,30$; $2,67 \mathrm{~V}$ dan waktu pengelasan $3 ; 4 ; 5 ; 7,5 \mathrm{~s}$. Hasil penelitian ini menunjukkan bahwa tegangan 2,67 V dan waktu pengelasan 7,5 s menghasilkan kekuatan tarik geser tertinggi yaitu 11,19 kN dengan mode kerusakan berupa pull out. Peningkatan tegangan listrik dan waktu pengelasan menyebabkan diameter nugget sisi antarmuka semakin lebar. HAZ mengalami perluasan akibat meningkatnya waktu pengelasan. Kekerasan tertinggi terdapat pada daerah nugget dikarenakan butiran terbentuk kolumnar.
\end{abstract}

Kata kunci: Resistance spot welding, Logam tak sejenis, Tegangan listrik, Waktu pengelasan

\begin{abstract}
Joining three sheets by resistance spot welding was an increasing trend in automotive assembly. Effect parameter of welding such us voltage and welding times to physics and mechanical properties resistance spot weld joint dissimilar metals three sheets 316L, SS 400, J1 was determined. Electroda pressure was kept constant in this result. The parameter of welding was used in this experiment were $2.02 ; 2.30 ; 2.67 \mathrm{~V}$ and $3 ; 4 ; 5 ; 7.5 \mathrm{~s}$. As a result of the experiment, it was determined that voltage $2.67 \mathrm{~V}$ and welding times $7.5 \mathrm{~s}$ result tensile shear load was $11.19 \mathrm{kN}$ with pull out failure mode. The increasing of voltage and welding times cause higher fusion zone size along sheet/sheet interface. The area of HAZ was increased because there was an increase in the welding times. The higher hardness was a nugget because grain was formed columnar.
\end{abstract}

Keywords: Resistance spot welding, Dissimilar metals, Voltage, Welding times

\section{PENDAHULUAN}

Tuntutan bagi perusahaan otomotif dalam memenuhi permintaan pasar untuk menghasilkan produk yang berkualitas merupakan aspek penting yang menjadi target perusahaan saat ini. Setiap material yang ditujukan untuk penggunaan otomotif khususnya pada bagian panel bodi harus memiliki kriteria mampu bentuk (formable), mampu las (weldable), tahan terhadap korosi (coatable) dan mampu diperbaiki. Dalam industri otomotif, terutama industri kendaraan roda empat dan kereta api sebagian besar menggunakan proses pengelasan. Proses yang sering digunakan yaitu spot welding dan seam welding. Proses tersebut dipilih, karena sebagian besar bahan yang dipakai dalam proses perakitan bodi dan rangka kendaraan adalah pelat lembaran, sehingga apabila menggunakan proses las yang biasa seperti Submerged Arc Welding (SAW) dan Shielded Metal Arc Welding (SMAW), maka material tersebut akan mengalami penurunan sifat mekanik karena ketebalan dari material yang rendah. Proses las titik banyak digunakan tidak hanya di industri automotif, tetapi juga industri elektronik, penerbangan, dan sektor nuklir. Pouranvari [1] mengatakan bahwa kendaraan modern mengandung 2000 sampai 5000 sambungan las titik.

Las titik (Resistance Spot Welding) merupakan metode pengelasan yang tepat untuk digunakan dalam dunia indutri. Hal ini dikarenakan dalam proses pengerjaannya membutuhkan waktu yang singkat. Pengelasan titik merupakan jenis las

16 Haikal, dkk.; Pengaruh Parameter Pengelasan Resistance Spot Welding Terhadap Sifat Fisik Dan Mekanik Multi-Layer Logam Tak Sejenis Berbeda Ketebalan 


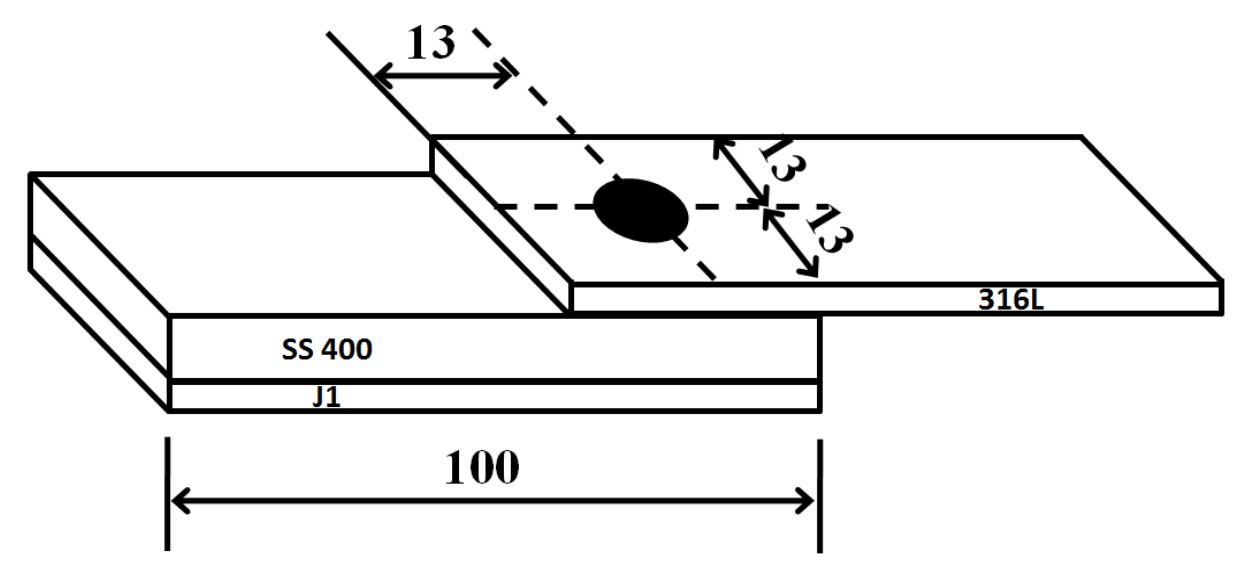

Gambar 1 Susunan pelat pada pengelasan titik multi-layer

Tabel 1 Komposisi kimia pelat stainless steel dan mild steel

\begin{tabular}{llll}
\hline Elemen & $316 \mathrm{~L}$ & $\mathrm{~J} 1$ & SS 400 \\
\hline $\mathrm{C}$ & 0,03 & 0,08 & 0,20 \\
$\mathrm{Mn}$ & 2,00 & $6,0-8,0$ & 0,53 \\
$\mathrm{P}$ & 0,045 & 0,070 & 0,01 \\
$\mathrm{~S}$ & 0,03 & 0,01 & 0,04 \\
$\mathrm{Si}$ & 0,75 & 0,75 & 0,09 \\
$\mathrm{Cr}$ & $16,00-18,00$ & $16,00-18,00$ & 0,03 \\
$\mathrm{Ni}$ & $10,00-14,00$ & $4,00-6,00$ & 0,03 \\
$\mathrm{Cu}$ & - & - & 0,159 \\
$\mathrm{Mo}$ & - & - & 0,048 \\
$\mathrm{~V}$ & - & - & 0,007 \\
\hline
\end{tabular}

Tabel 2 Sifat mekanik pelat stainless steel dan mild steel

\begin{tabular}{llll}
\hline Material & Yield Strength $(\mathrm{MPa})$ & Tensile Strength $(\mathrm{MPa})$ & $\begin{array}{l}\text { Elongation } \\
(\%)\end{array}$ \\
\hline SS 400 & 245 & 388 & 31 \\
J1 & 205 & 550 & 40 \\
316L & 170 & 485 & 40 \\
\hline
\end{tabular}

yang sangat efisien untuk industri yang menggunakan jalur produksi otomatis dan produksi secara massal. Metode las ini juga cocok untuk produksi kecil, karena fleksibel, peralatan proses sederhana, biaya relatif murah dan pengelasan mudah untuk dikontrol. Selain itu, keuntungan penting dari metode ini adalah bahwa las titik dapat digunakan untuk menggabungkan sejumlah besar bahan logam. Penggunaan pengelasan titik untuk menggabungkan dua material atau lebih yang berbeda jenis merupakan upaya penghematan biaya. Hal ini telah banyak dilakukan oleh perusahaan baik dalam bidang manufaktur maupun industri otomotif. Salah satu contoh penerapan las titik menggunakan logam berbeda material adalah pembuatan struktur dinding gerbong dan pintu kereta api. Struktur bodi kereta api ini terdiri dari pelat tipis yang disebut sheeting dan diperkuat oleh rangka (frame). Mild steel merupakan baja karbon rendah yang biasa digunakan untuk pembuatan rangka bodi kereta api. Logam tersebut memiliki kandungan karbon antara 0,16 s/d 0,2\%. Kelebihan dari mild steel adalah logam ini mudah ditempa dan dimesin. Logam ini banyak digunakan hampir semua sektor industri terutama industri manufaktur karena harganya relatif murah. Akan tetapi, mild steel memiliki kekurangan yaitu tidak tahan terhadap korosi. Oleh karena itu logam tersebut perlu dilindungi dengan menggabungkan logam tahan korosi seperti aluminium, timah, seng, nikel, krom dan lain sebagainya. Penelitian banyak dilakukan untuk mengetahui karateristik hasil las titik untuk logam yang berbeda jenis. Penelitian terhadap 
las titik banyak dilakukan oleh peneliti sebelumnya yaitu Vural dkk [2] yang meneliti sifat mekanik sambungan las titik logam yang berbeda antara baja tahan karat dengan baja galvanis. Hasil penelitian tersebut menunjukkan bahwa perbedaan jenis logam berpengaruh terhadap bentuk diameter nugget. Uji struktur makro menunjukkan bentuk diameter nugget tidak simetris (asimetris). Ketidaksimetrisan bentuk nugget hasil las diakibatkan panas yang tidak seimbang. Bentuk asimetris nugget bedampak menurunnya kekuatan geser hasil las.

Penggunaan las titik untuk menggabungkan logam lebih dari 2 lapis merupakan pengembangan baru dalam perakitan automotif. Dibandingkan dengan dua lapisan logam, untuk menggabungkan tiga atau lebih lapisan logam jauh lebih rumit karena memiliki sisi antarmuka lebih banyak [3-6]. Contoh konstruksi yang menggunakan sambungan tiga lapis adalah pintu kereta api. Baja SS 400 dijadikan sebagai rangka dan baja tahan karat sebagai pelindung logam tersebut. Pengelasan ini dilakukan dengan menggunakan metode las titik. Penelitian terhadap las titik tiga lapis sudah dilakukan oleh peneliti sebelumnya yaitu Nielsen dkk [7] yang melakukan penelitian tentang pengaruh waktu pengelasan terhadap sambungan las tiga lapis baja berkekuatan tinggi. Ninshu dan Hidekazu [8] mempelajari pengaruh kuat arus listrik dan waktu pengelasan terhadap diameter nugget pada las titik untuk bodi automotif dengan menggunakan metode FEM (Finite Element Method). Pouranvari dan Marashi [9] melakukan penelitian tentang pengaruh waktu pengelasan terhadap ukuran diameter nugget pada tebal pelat yang sama. Ketiga penelitian di atas fokus pada pengaruh waktu pengelasan terhadap ukuran diameter nugget sedangkan pengaruh tegangan listrik belum menjadi perhatian dalam penelitian tersebut. Oleh karena itu perlu dilakukan penelitian lebih mendalam tentang pengaruh tegangan listrik dan waktu pengelasan terhadap sifat fisik dan mekanik sambungan las titik logam tak sejenis tiga lapis yang berbeda tebal.

\section{BAHAN DAN METODE}

Baja tahan karat tipe austenit (316L dan J1) dan baja paduan (SS 400) dalam bentuk pelat dengan ukuran masing-masing 125 x 80 x $3 \mathrm{~mm}$ telah digunakan dalam penelitian ini. Komposisi kimia dan sifat-sifat mekanik dari material tersebut ditunjukkan pada tabel 1 dan 2. Mesin yang digunakan untuk melakukan pengelasan adalah mesin las titik tipe DN16-1 AC Point Welder dengan Rated Power 16 kVA. Skema penelitian yang dilakukan dapat dilihat pada gambar 1. Material disusun dengan susunan 3 lapis urut dari atas, tengah dan bawah yaitu $316 \mathrm{~L}$, SS 400,
J1 sesuai dengan aplikasi pada pintu kereta api. Parameter yang digunakan selama proses pengelasan ditunjukkan pada tabel 3. Karakterisasi sambungan las titik

Pengamatan mikrostruktur dilakukan menggunakan mikroskop optik dengan standar ASTM E407-07. Pengujian ini dilakukan untuk mengetahui karakteristik struktural pada logam. Prosuder untuk pengamatan mikrostruktur diawali dengan proses pemotongan, mounting, polishing dan terakhir etsa. Proses etsa dilakukan secara 2 kali pencelupan dalam laurtan etsa dikarenakan properti kedua material sangat berbeda. Larutan etsa yang digunakan yaitu larutan Nital dimana $5 \mathrm{ml}$ asam nitrat $\mathrm{HNO}_{3}$ dan $100 \mathrm{ml}$ alkohol untuk etsa baja SS 400 . Sedangkan larutan etsa untuk baja 316L dan J1 adalah $10 \mathrm{ml}$ asam nitrat, $20 \mathrm{ml}$ asam klorida and $30 \mathrm{ml}$ air.

Pengujian tarik dilakukan untuk mengetahui sifat mekanis bahan yaitu kekuatan tarik geser. Pengujian ini menggunakan mesin uji tarik UTM (Universal Testing Machine) dengan standar AWS D8.9-97.

Uji kekerasan dilakukan dengan menggunakan metode vickers dengan standar ASTM E92-82. Pengujian vickers dilakukan untuk mengetahui ketahanan suatu logam terhadap deformasi plastis. Pengujian ini terdapat 25 titik kekerasan dengan tekanan indentor sebesar $200 \mathrm{~g}$ (HV0.2) dan load holding time selama 10 detik.

Tabel 3 Parameter proses pengelasan

\begin{tabular}{ll}
\hline Parameter & Nilai \\
\hline Elektroda & $\mathrm{Cu}$ \\
Diameter tip elektroda & $8 \mathrm{~mm}$ \\
Medium pendingin & Air \\
Tegangan listrik & $2,02-2,67 \mathrm{~V}$ \\
Waktu pengelasan & $3-7,5 \mathrm{~s}$ \\
Holding time & $30 \mathrm{~s}$ \\
\hline
\end{tabular}

\section{HASIL DAN PEMBAHASAN}

\section{Struktur Makro dan Mikro (Metalografi)}

Tegangan listrik dan waktu pengelasan merupakan parameter yang sangat berpengaruh terhadap hasil sambungan las titik. Gambar 2 menunjukkan foto makro hasil pengelasan titik dengan susunan pelat 3 lapis. Nugget terbentuk akibat adanya panas yang muncul (heat input) sangat tinggi sehingga dapat membuat logam mengalami peleburan. Heat input pada pengelasan titik dipengaruhi oleh beberapa faktor yaitu kuat arus listrik, hambatan, dan waktu pengelasan [10]. Kuat arus listrik selalu berbanding lurus dengan tegangan listrik, hal ini sesuai dengan pernyataan hukum ohm. Oleh karena itu, semakin tinggi tegangan listrik 
berdampak semakin meningkatnya heat input. Tegangan listrik memberikan pengaruh lebih besar terhadap ukuran diameter nugget dibandingkan waktu pengelasan seperti ditunjukkan pada gambar 3 . Tegangan 2,02 $\mathrm{V}$ dengan waktu pengelasan 3 dan 4 detik menghasilkan peleburan yang hanya muncul pada sisi antarmuka pelat. Panas yang muncul pada parameter tersebut tidak cukup untuk meleburkan ketiga logam secara keseluruhan. Tegangan 2,02 V dengan waktu pengelasan 5 detik merupakan parameter kritis dimana ketiga logam tersebut dapat melebur secara menyeluruh. Kenaikan tegangan listrik juga berdampak meningkatnya penetrasi nugget hasil lasan. Penetrasi merupakan kedalaman nugget menembus sampai ke dalam tebal pelat. Kedalaman minimum penetrasi dari las titik umumnya adalah $20 \%$ dari ketebalan pelat. Menurut Hayat peningkatan penetrasi nugget menyebabkan kekuatan tarik geser sambungan las titik juga meningkat [11].

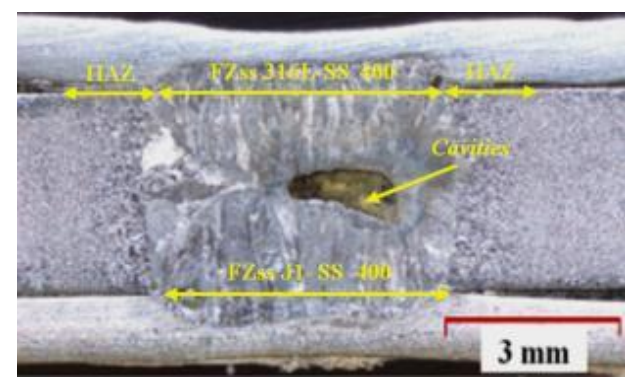

\section{Gambar 2 Struktur makro daerah lasan}

Gambar 3 menunjukkan pengaruh tegangan listrik dan waktu pengelasan terhadap diameter nugget sisi antarmuka (FZss) antara 316L-SS 400 dan J1-SS 400. Tegangan 2,02 V menghasilkan peningkatan diameter nugget sisi antar muka tidak signifikan seiring dengan meningkatnya waktu pengelasan. Heat input yang muncul pada tegangan 2,02 $\mathrm{V}$ dengan waktu pengelasan 5 dan 7,5 detik tidak tinggi disertai dengan panas yang terdistribusi ke arah sheet tengah (SS 400). Hal ini mengakibatkan panas yang muncul pada sisi antarmuka berkurang seiring meningkatnya waktu pengelasan. Tegangan 2,30 $\mathrm{V}$ menghasilkan peningkatan diameter nugget sisi antar muka yang signifikan seiring dengan meningkatnya waktu pengelasan. Heat input yang muncul pada tegangan $2,30 \mathrm{~V}$ dengan waktu pengelasan 5 dan 7,5 detik jauh lebih tinggi dibandingkan tegangan $2,02 \mathrm{~V}$. Tegangan 2,67 V menghasilkan diameter nugget sisi antar muka lebih tinggi dibandingkan tegangan $2,02 \mathrm{~V}$ dan $2,30 \mathrm{~V}$. Penurunan pertumbuhan nugget secara signifikan terjadi pada tegangan $2,67 \mathrm{~V}$ seiring meningkatnya waktu pengelasan. Semakin tinggi tegangan listrik dan waktu pengelasan mengakibatkan terjadinya penurunan hambatan resistansi dinamik $(\mu \Omega)$. Hambatan resistansi dinamik berbanding lurus dengan hambatan sheet. Penurunan hambatan sheet mengakibatkan pertumbuhan diameter nugget sisi antar muka menurun. Secara teoritis tegangan 2,67 V dengan waktu pengelasan 3 detik menghasilkan heat input lebih rendah dibandingkan tegangan $2,30 \mathrm{~V}$ dengan waktu pengelasan 7,5 detik, tetapi diameter nugget sisi antar muka yang dihasilkan lebih tinggi. Hal ini dikarenakan heat input yang muncul pada tegangan 2,30 V terdistribusi ke arah sheet tengah yang memiliki konduktifitas termal tinggi. Panas yang terdistribusi pada waktu pengelasan 7,5 detik lebih banyak dibandingkan waktu pengelasan 3 detik.

Struktur makro menunjukkan bahwa sebagian besar hasil lasan untuk semua variasi tegangan dan waktu pengelasan menghasilkan cacat berupa lubang (cavities). Cavities terbentuk akibat adanya penyusutan (shrinkage) pada saat nugget mengalami proses pembekuan. Pembekuan ini terjadi dikarenakan logam memiliki konduktifitas termal yang mengakibatkan panas ditransferkan ke lingkungan. Bagian terluar dari nugget mengalami pembekuan terlebih dahulu sehingga leburan pada bagian tengah akan tertarik ke arah luar nugget. Cacat tersebut tidak memberikan pengaruh yang signifikan terhadap kekuatan statis dan dinamis sambungan las. Hal ini dikarenakan tegangan bernilai nol pada daerah tengah sambungan las.

Uji struktur mikro dilakukan untuk mengambil foto mikro pada daerah logam induk, HAZ, dan nugget. Logam induk merupakan daerah terkena panas tetapi tidak mengalami perubahan struktur mikro seperti ditunjukkan pada gambar 5 . Gambar 6 menunjukkan struktur mikro daerah nugget dan HAZ. HAZ (Heat Effected Zone) merupakan daerah terkena panas dan mengalami perubahan struktur mikro tetapi tidak sampai terjadi peleburan. Nugget merupakan daerah logam las yang mengalami peleburan dan kemudian membeku. Hasil uji mikro menunjukkan daerah logam induk baja SS 400 terdiri dari fasa ferit dan perlit $(\mathrm{Fe}+\mathrm{Fe} 3 \mathrm{C})$. Ferit memiliki warna terang sedangkan perlit cenderung bewarna gelap. Ferit pada baja tahan karat memiliki warna gelap dan austenit bewarna terang disertai dengan adanya kembaran anil (annealing twins). Annealing twins merupakan kembaran anil yang terbentuk akibat adanya proses heat treatment pada pembuatan pelat stainless steel. Kembaran ini hanya muncul pada logam yang memiliki struktur kristal FCC (Face Center Cubic).

Hasil penelitian ini menunjukkan baja SS 400 memiliki 3 daerah HAZ. HAZ 1 merupakan daerah HAZ yang terletak berdekatan dengan logam induk. Temperatur pada HAZ 1 tidak terlalu tinggi disertai pendinginan yang lambat sehingga daerah ini memiliki ukuran butir ferit $\alpha$ dan perlit yang lebih 
besar dibandingkan daerah logam induk. Ukuran butir mengalami perubahan dari ukuran besar (HAZ 1) menjadi lebih kecil, bahkan lebih kecil dibandingkan logam induk yaitu pada daerah HAZ 2. Penghalusan butir (grain refinement) terjadi pada HAZ 2. HAZ 3 merupakan daerah HAZ yang terletak berdekatan dengan nugget. Pengkasaran butir (grain coarsened) terjadi pada daerah HAZ 3 sehingga butir ferit terlihat kasar.

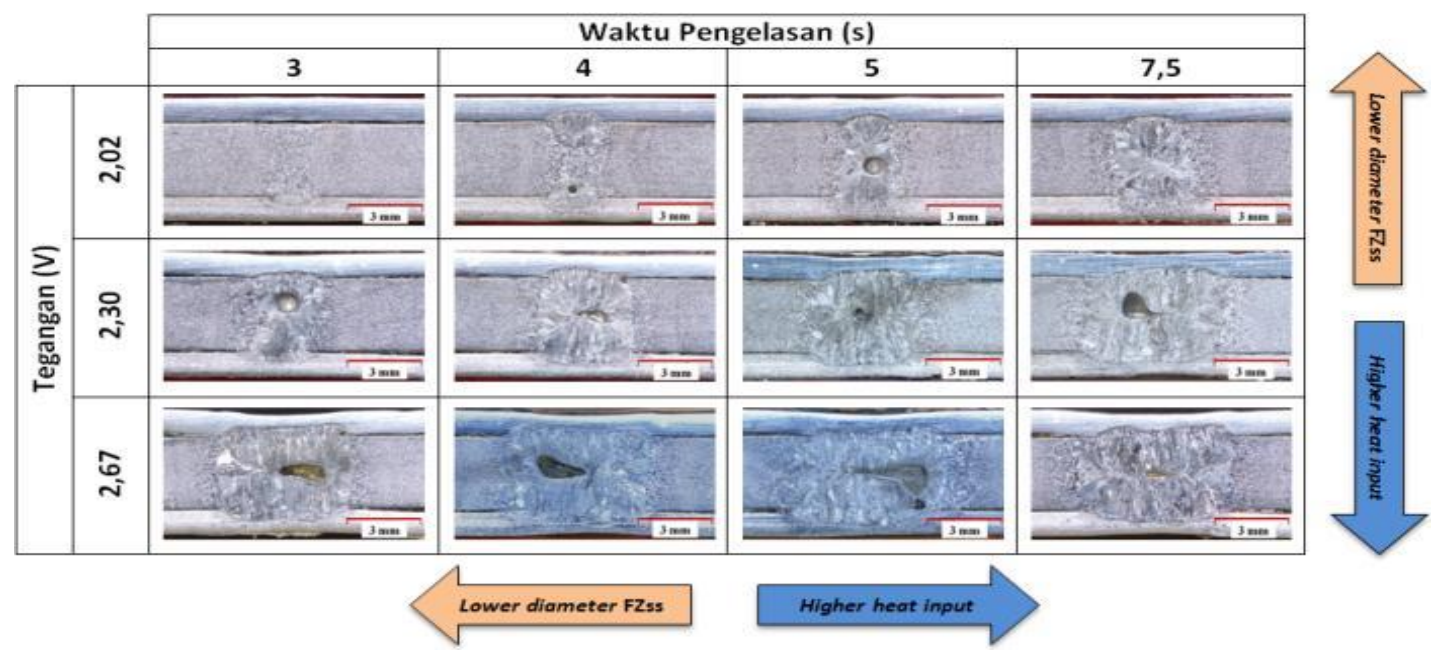

Gambar 3 Struktur makro sambungan las

Hasil uji mikro menunjukkan baja tahan karat J1 dan 316L hanya memiliki satu daerah HAZ untuk semua variasi tegangan listrik dan waktu pengelasan. Ukuran butir tumbuh menjadi besar akibat terkena panas yang tidak terlalu tinggi disertai dengan pendinginan yang lambat. Luasan area HAZ dipengaruhi oleh konduktifitas termal logam tersebut. Konduktifitas termal adalah kemampuan suatu material untuk mendistribusikan panas dari suhu tinggi ke suhu rendah. Baja karbon rendah memiliki konduktifitas termal yang tinggi yaitu sekitar 52 W. $\mathrm{m}^{-1} \mathrm{~K}^{-1}$, sedangkan baja tahan karat sekitar 16,2 $\mathrm{W} \cdot \mathrm{m}^{-1} \mathrm{~K}^{-1}$. Konduktifitas termal baja karbon lebih tinggi dibandingkan baja tahan karat, sehingga daerah HAZ yang dihasilkan baja SS 400 lebih luas dibandingkan baja tahan karat J1 dan 316L. Peningkatan waktu pengelasan menyebabkan butir pada daerah HAZ baja tahan karat semakin besar dan luas.

Nugget merupakan daerah logam yang mengalami peleburan dan pendinginan cepat, sehingga menghasilkan bentuk butir yang jauh berbeda dibandingkan logam induk dan HAZ. Daerah ini memiliki bentuk butir berupa kolom panjang (columnar). Arah pembentukan butir columnar searah dengan arah gaya penekanan elektroda.

\section{Kekuatan tarik geser (Tensile load bearing capacity)}

Pengujian geser dilakukan untuk mengetahui kemampuan sambungan las titik menahan beban. Beban yang diberikan pada sambungan las titik merupakan beban statik. Hasil penelitian menunjukkan tegangan listrik dan waktu pengelasan berpengaruh terhadap tensile load bearing capasity (TLBC) sambungan las. Peningkatan tensile load bearing capasity terjadi dikarenakan meningkatnya tegangan listrik dan waktu pengelasan.

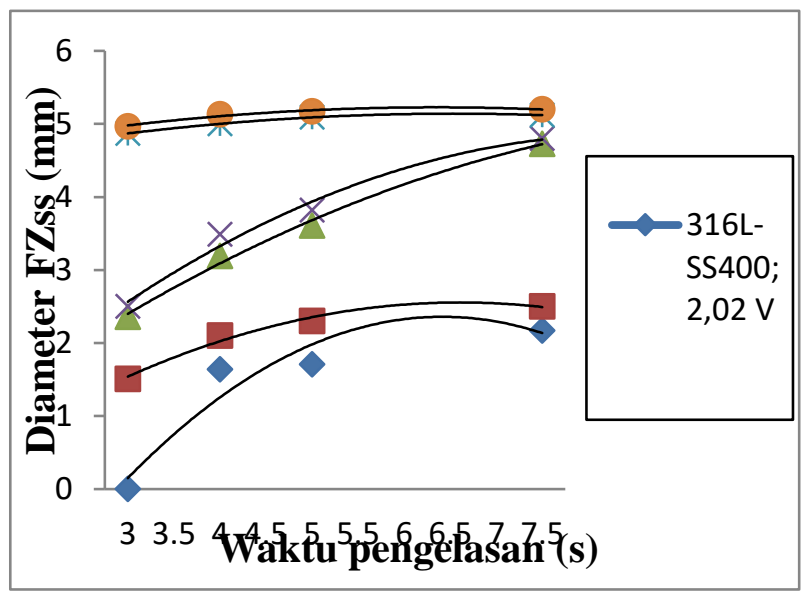

\section{Gambar 4 Hubungan antara tegangan listrik dan waktu pengelasan dengan diameter sisi antarmuka (FZss)}

Gambar 4 menunjukkan untuk tegangan $2,02 \mathrm{~V}$ pada variasi waktu pengelasan $3 ; 4 ; 5 ; 7,5$ detik memiliki kemampuan daya beban dukung sebesar 0 kN. Mesin UTM (Universal Testing

20 Haikal, dkk.; Pengaruh Parameter Pengelasan Resistance Spot Welding Terhadap Sifat Fisik Dan Mekanik Multi-Layer Logam Tak Sejenis Berbeda Ketebalan 
Machine) yang digunakan merupakan mesin dengan pencekam otomatis. Daya beban dukung yang dimiliki tegangan 2,02 $\mathrm{V}$ untuk semua variasi tidak mampu menahan beban yang ditimbulkan saat pencekaman, sehingga sambungan terlepas sebelum ditarik. Tegangan $2,30 \mathrm{~V}$ pada variasi waktu pengelasan $3 ; 4 ; 5 ; 7,5$ detik memiliki kemampuan daya beban dukung sebesar 7,61 kN; 8,19 kN; 8,61 $\mathrm{kN} ; 9,18 \mathrm{kN}$, sedangkan tegangan $2,67 \mathrm{~V}$ sebesar $10,37 \mathrm{kN} ; 10,64 \mathrm{kN} ; 10,92 \mathrm{kN} ; 11,19 \mathrm{kN}$. Tensile load bearing capasity meningkat seiring dengan meningkatnya diameter nugget hasil sambungan las.
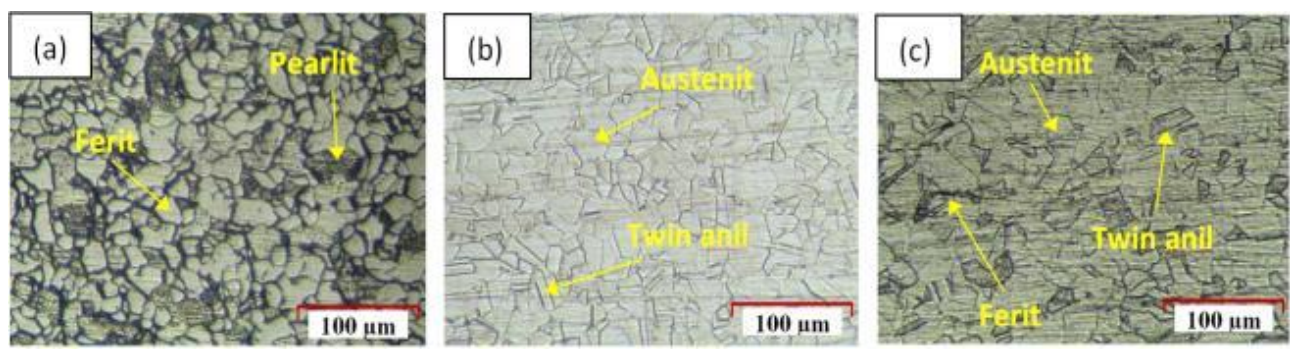

Gambar 5 Struktur mikro logam induk: (a) SS 400, (b) 316L, (c) J1

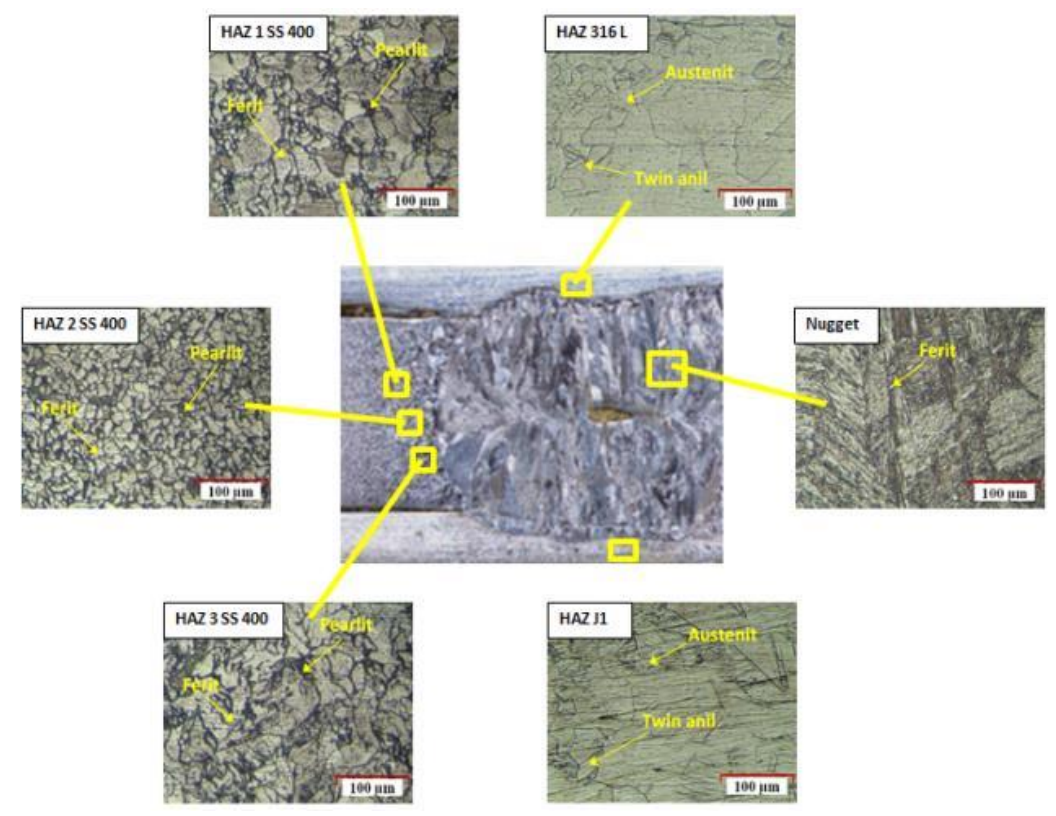

Gambar 6 Struktur mikro daerah lasan

Gambar 5 menunjukkan jenis kegagalan yang dihasilkan dalam penelitian las ini terdiri dari dua jenis mode kegagalan yaitu interfacial failure mode dan pull out failure mode. Hasil penelitian ini menunjukkan tegangan $2,02 \mathrm{~V}$ dan $2,30 \mathrm{~V}$ untuk variasi waktu pengelasan $3 ; 4 ; 5 ; 7,5$ detik menghasilkan kegagalan interfacial failure mode, sedangkan 2,67 V berupa pull out failure mode. Pull out failure mode merupakan jenis kegagalan hasil sambungan las titik yang memiliki tensile load bearing capasity tinggi.

\section{Kekerasan mikro (vickers microhardness)}

Pengujian keras vickers dilakukan untuk mengetahui kekerasan pada logam induk, HAZ dan nugget. Uji keras vickers dilakukan secara diagonal. Hasil penelitian menunjukkan logam induk baja karbon SS 400 memiliki kekerasan sebesar \pm 93 HV0.2, baja tahan karat J1 sebesar \pm 163 HV0.2 dan 316L sebesar \pm 145 HV0.2, sedangkan daerah nugget memiliki kekerasan di atas 240 HV0.2. Nugget memiliki kekerasan yang sangat tinggi dikarenakan daerah ini memiliki bentuk butir columnar disertai adanya fasa martensit. Daerah HAZ memiliki kekerasan lebih tinggi dibandingkan logam induk. Kekerasan HAZ 
mengalami peningkatan ketika berdekatan dengan nugget untuk semua variasi tegangan listrik dan waktu pengelasan. Kekerasan meningkat dikarenakan HAZ mengalami pengkasaran butir akibat suhu yang tinggi dan waktu pendinginan yang cukup cepat [12].

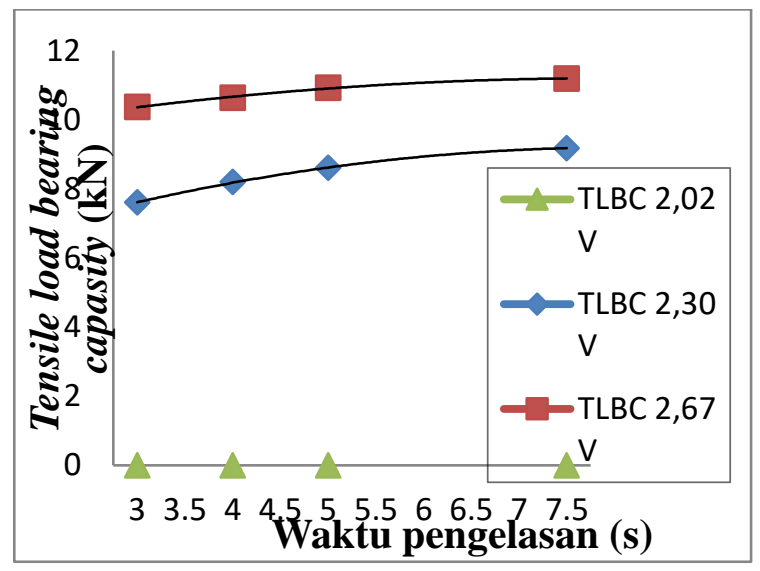

Gambar 7 Pengaruh waktu pengelasan terhadap daya beban dukung tarik geser sambungan las

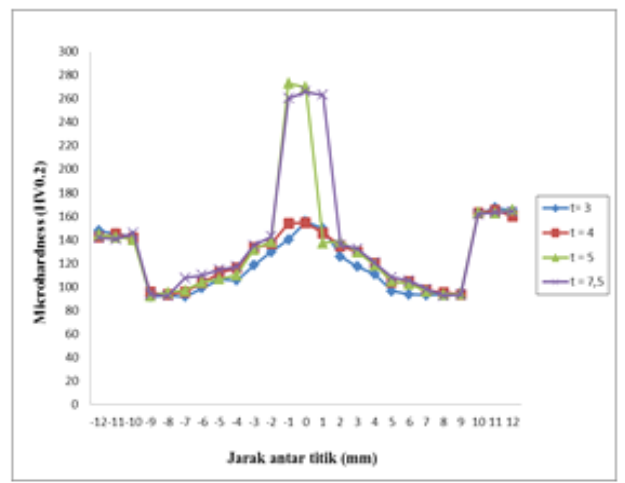

(a)

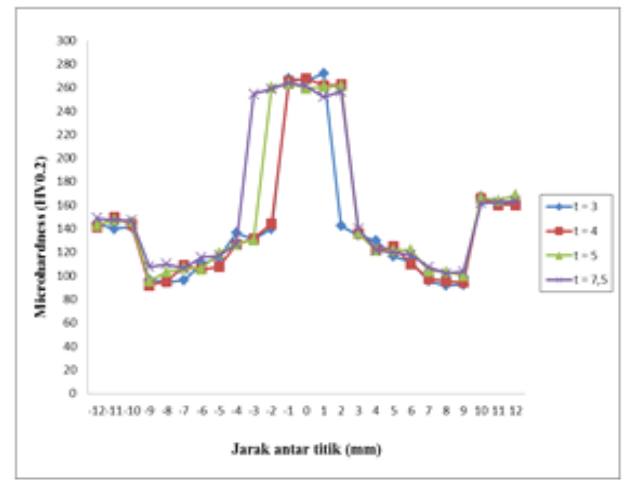

(b)

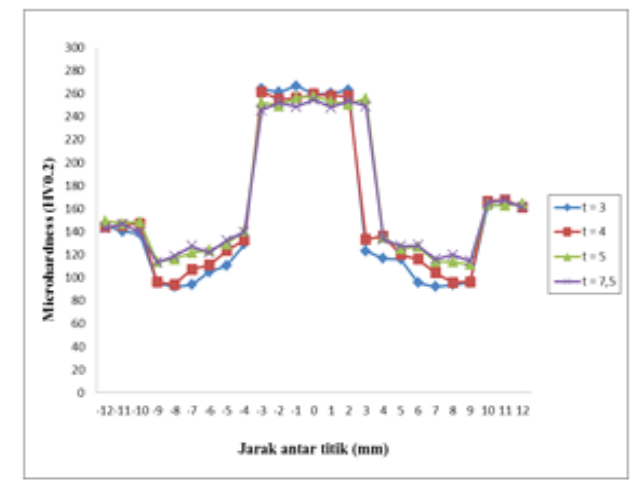

(c)

Gambar 8 Distribusi kekerasan pada daerah lasan pada tegangan listrik: (a) 2,02 V, (b) 2,30 V, 2,67 V 


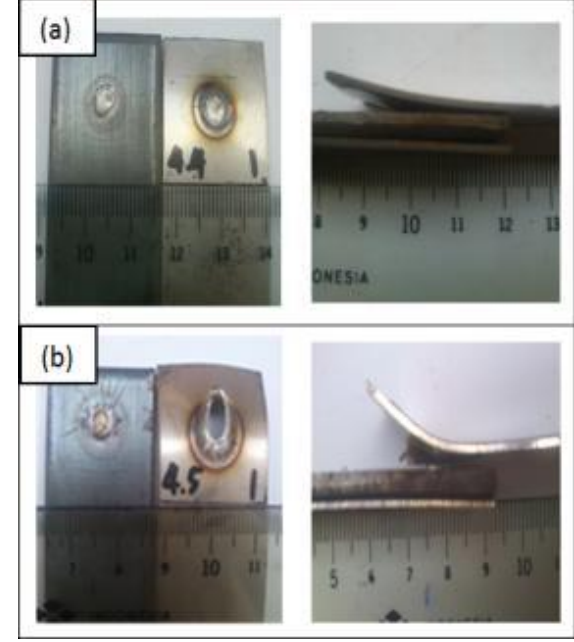

Gambar 9 Mode kegagalan hasi uji tarik geser: (a) interfacial failure mode, (b) pull out failure mode

Gambar 9 menunjukkan kekerasan nugget pada tegangan 2,02 $\mathrm{V}$ dengan waktu pengelasan 5; 7,5 detik sebesar \pm 271 HV0.2 dan \pm 262 HV0.2. Waktu pengelasan 3 dan 4 detik menghasilkan kekerasan pada daerah nugget sebesar \pm 130 HV0.2. Kekerasan daerah nugget mengalami penurunan yang sangat signifikan karena waktu pengelasan 3 dan 4 detik hanya terjadi fusi pada sisi antarmuka. Tegangan 2,30 V menghasilkan nugget lebih luas dibandingkan tegangan $2,02 \mathrm{~V}$ untuk semua variasi waktu pengelasan seperti ditunjukkan pada gambar 4.21. Kekerasan nugget yang dihasilkan pada tegangan $2,30 \mathrm{~V}$ dengan waktu pengelasan $3 ; 4 ; 5 ; 7,5$ detik sebesar \pm 268 HV0.2; \pm 264 HV0.2, \pm 260 HV0.2; \pm 257 HV0.2. Tegangan 2,67 V menghasilkan nugget yang lebih luas dibandingkan tegangan $2,02 \mathrm{~V}$ dan 2,30 V untuk semua variasi waktu pengelasan seperti ditunjukkan pada gambar 4.22. Kekerasan nugget yang dihasilkan pada tegangan $2,67 \mathrm{~V}$ dengan waktu pengelasan $3 ; 4 ; 5 ; 7,5$ detik sebesar \pm 262 HV0.2; \pm 258 HV0.2, \pm 253 HV0.2; \pm 250 HV0.2.

\section{KESIMPULAN}

Penelitian tentang pengaruh tegangan listrik dan waktu pengelasan terhadap sifat fisik dan mekanik hasil sambungan las titik 3 lapis 316L-SS 400-J1 telah dilakukan. Berdasarkan analisis data dan pembahasan dapat diambil beberapa kesimpulan sebagai berikut:

1. Pengelasan antara baja karbon rendah dengan baja tahan karat untuk semua variasi tegangan listrik dan waktu pengelasan menghasilkan struktur butir columnar di daerah nugget.
2. Kekuatan sambungan las titik (tensile shear load bearing capasity) tertinggi terdapat pada tegangan 2,67 $\mathrm{V}$ dan waktu pengelasan 7,5 detik sebesar $11,19 \mathrm{kN}$ dengan tipe kerusakan berupa pull out failure mode.

3. Kekerasan tertinggi terdapat pada daerah nugget sebesar \pm 260 HV0.2 dan distribusi kekerasan pada daerah nugget hampir sama untuk semua variasi tegangan listrik dan waktu pengelasan.

\section{DAFTAR PUSTAKA}

[1] M. Pouranvari, "Effect of welding current on the mechanical response of resistance spot welds of unequal thickness steel sheets in tensile-shear loading condition," International Journal of Multidisciplinary Sciences and Engineering, vol. 2, pp. 178-189, 2011.

[2] M. Vural, A. Akkuş, and B. Eryürek, "Effect of welding nugget diameter on the fatigue strength of the resistance spot welded joints of different steel sheets," Journal of Materials Processing Technology, vol. 176, pp. 127-132, 2006.

[3] H. Eizadi and S. Marashi, "On the resistance spot welding of four-sheet stack of unequal sheet thickness," Science and Technology of Welding and Joining, vol. 21, pp. 632-637, 2016.

[4] Y. Li, F. Yan, Z. Luo, Y. Chao, S. Ao, and X. Cui, "Weld growth mechanisms and failure behavior of three-sheet resistance spot welds made of 5052 aluminum alloy," Journal of Materials Engineering and Performance, vol. 24, pp. 2546-2555, 2015.

[5] S. Wei, R. Liu, D. Lv, L. Lin, R. Xu, J. Guo, et al., "Weldability and mechanical properties of similar and dissimilar resistance spot welds of three-layer advanced high strength steels," Science and Technology of Welding and Joining, vol. 20, pp. 20-26, 2015.

[6] R. Chtourou, N. Leconte, F. Chaari, G. Haugou, É. Markiewicz, and B. Zouari, "Macro-modeling of the strength and failure of multi-layer multisteel grade spot welds: Connector formulation, assembly model and identification procedure," Thin-Walled Structures, vol. 113, pp. 228-239, 2017.

[7] C. V. Nielsen, K. S. Friis, W. Zhang, and N. Bay, "Three-sheet spot welding of advanced highstrength steels," Welding journal, vol. 90, 2011.

[8] N. Ma and H. Murakawa, "Numerical and experimental study on nugget formation in resistance spot welding for high strength steel sheets in automobile bodies," Transactions of JWRI, vol. 38, pp. 19-24, 2009.

[9] M. Pouranvari and S. Marashi, "Critical sheet thickness for weld nugget growth during 
resistance spot welding of three-steel sheets," Science and Technology of Welding and Joining, vol. 16, pp. 162-165, 2011.

[10]S. Aslanlar, "The effect of nucleus size on mechanical properties in electrical resistance spot welding of sheets used in automotive industry," Materials \& Design, vol. 27, pp. 125131, 2006.
[11]F. Hayat, "Resistance spot weldability of dissimilar materials: BH180-AISI304L steels and BH180-IF7123 steels," Journal of Materials Science \& Technology, vol. 27, pp. 1047-1058, 2011.

[12]W. Harsono and T. Okumura, "Teknologi Pengelasan Logam Pradnya Paramita," ed: Jakarta, 1981. 